\title{
PrX II AND CKBB PROTEINS INTERACTION UNDER PHYSIOLOGICAL AND THERMAL STRESS CONDITIONS IN A549 AND HeLa CELLS
}

\author{
A. D. RAKHMETOV ${ }^{1}$, LEE SANG PIL ${ }^{2}$, L. I. OSTAPCHENKO', CHAE HO ZOON² \\ ${ }^{1}$ Education and Science Center Institute of Biology, \\ Taras Shevchenko National University of Kyiv, Ukraine; \\ ${ }^{2}$ Chonnam National University, Biochemistry Department, Gwangju, South Korea; \\ e-mail: anar.rakhmetov@gmail.com
}

Peroxiredoxins (Prxs) are versatile enzymes that demonstrate various cell functions as peroxidases, protein chaperones, functions of signal modulators and binding partners. It is well established that Prxs can interact with multiple proteins in cells, such as ASK1, Cdk5-p35, JNK, MIF, PDGF, TKR4 and others. In this study, we attempted to evaluate a possible association between ubiquitous Prx II and ATP/ADP buffering enzyme - brain-type creatine kinase (CKBB). Our co-immunoprecipitation (Co-IP) results from the A549 and HeLa cell lysates with overexpressed HA-Prx II and Flag-CKBB have demonstrated strong association between two proteins under non-stressed conditions. This protein interaction was enhanced by the heat treatment with further HA-Prx II precipitation to the immobilized Flag-CKBB depending on the temperature increase. Temperature induced oligomerization of Prx II may contribute to the formation of Prx II conglomerates, which in turn, can associate with CKBB and increase signal intensities on the blotted membranes. Thus, such association and oligomerization of Prx II could take part in recovery and protection of the CKBB enzyme activity from inactivation during heat-induced stress.

Key word s: peroxiredoxin II, heat stress, creatine kinase, western blotting.

$\mathrm{P}$

eroxiredoxins are molecules that possess peroxidase and chaperone protein functions [1, 2]. They are ubiquitous peroxidases that reduce harmful peroxides and peroxinitrites based on the thiol active center. The conserved cysteine (Cys) amino acid common for all Prx species is the catalytically active residue of paramount importance. Depending on the number of Prx subunits, position and number of Cys residues, family of peroxiredoxins may be divided into two sub-families: 1-Cys Prxs and 2-Cys Prxs, whereas the 2-Cys Prxs include two classes known as the "typical" and "atypical" [3]. Mammalian cells express six isoforms of Prx named respectively from Prx I to Prx VI. Homodimeric Prx I to Prx IV belong to the "typical" 2-Cys sub-group, Prx V to the "atypical", and Prx VI to the 1-Cys sub-group [4].

With more than $70 \%$ of aminoacid sequence identity, four 2-Cys sub-family members possess conserved N-terminal and C-terminal cysteine residues giving, therefore to each homodimer two pairs of "peroxidatic" and "resolving" cysteines [5]. The role of "peroxidatic" Cys that locates at the N-ter- minal region is to reduce peroxides $\left(\mathrm{H}_{2} \mathrm{O}_{2}, \mathrm{ROOH}\right.$, $\mathrm{ONOO}^{-}$) with further transformation to a sulfenic acid derivative $\left(\mathrm{S}_{\mathrm{p}}-\mathrm{OH}\right)$. Oxidized $\mathrm{SP}$, in turn interacts with the resolving $\left(\mathrm{S}_{\mathrm{R}}\right)$ Cys of the other monomer in the dimer to form an intermolecular disulfide bond. On condition of excessive peroxide generation, Cys- $\mathrm{S}_{\mathrm{p}} \mathrm{OH}$ can react with a second $\mathrm{H}_{2} \mathrm{O}_{2}$ molecule that makes it transit to a hyperoxidized state of Cys sulfinic acid $\left(\mathrm{Cys}-\mathrm{S}_{\mathrm{P}} \mathrm{O}_{2}^{-}\right)$[6, 15]. In order to reduce an oxidized peroxiredoxin with $S_{P}-S_{R}$ disulfide bond, cells possess a Trx system, composed of Trx, thioredoxin reductase, and NADPH. On the other hand, an overoxidized sulfinic derivative can be reversed to a sulfenic form by the Sulfiredoxin (Srx) enzyme, in the presence of MgATP [7, 8].

Peroxiredoxin II (Prx II, EC 1.11.1.15) belonging to the 2-Cys Prx sub-family is a cytosolic enzyme, which consists of 199 residues. Levels of Prx II expression are elevated in various cancers (mesothelioma, breast, and head cancers) and shown to affect diverse cellular processes $[9,10,11]$. Overexpression of Prx II grants drug resistance to leukemia and stomach cancer cells, while down-regulation 
of Prx II makes head-and-neck cancer cell sensitive to radiation [12, 13]. Prx II was observed as preventing agent against the development of hemoglobin aggregation in hemolytic anemia [14].

Human brain creatine kinase (BCK, monomer, CKBB, dimer) is a cytosolic homodimer protein with molecular weight of one subunit of $\sim 42 \mathrm{kDa}$. The enzyme is mainly expressed in the brain tissue, where it catalyzes the reversible transfer of the $\gamma$-phosphoryl group of ATP molecule to creatine, resulting in generation of phosphocreatine and ADP, which play a role of 'temporal energy buffer' according to [16]. It has been reported that CKBB is a major target of oxidative stress and the activity level of enzyme is gradually reduced in the brain affected by neurodegenerative diseases $[17,18]$. Also, it was suggested that a posttranslational modification may cause a decrease of CKBB activity in Alzheimer's patients [18]. Therefore, the impaired CKBB activity levels may greatly facilitate as an accurate biomarker to improve early detection of neurodegenerative diseases [19].

Specific interactions are common for all members of Prx family, where the number of identified clients increases annually. Prx I and Prx II show high plausibility to directly associate with various binding clients [4]. Recent study shows that Prx II, which is present at high concentration in the cytoplasm along with Prx I, can interact in hyperoxidised state with a member of protein disulfide isomerase family [20]. In this study, we present results indicating the protein-protein interaction of Prx II with brain type creatine kinase. CKBB was identified as a co-binding partner of exogenously expressed Prx II from both A549 and HeLa cell lines. To study whether the interaction is susceptible to outer stressors, the A549 and HeLa were treated with various elevated temperatures. Our results suggest that Prx II has markedly higher binding affinity under heat treatment than physiological conditions in A549 and HeLa cells.

\section{Materials and Methods}

Cell culture. A549 and HeLa cells were obtained from American Type Culture Collection. A549 cells were maintained with RPMI 1640 medium, and HeLa cells in Dulbecco's modified Eagles medium (WelGENE). Both were supplemented with $10 \%[\mathrm{v} / \mathrm{v}$ ] fetal bovine serum (WelGENE, Daegu, Korea), and $1 \%$ antimycotic antibiotic (Invitrogen). The growth temperature was $37{ }^{\circ} \mathrm{C}$ with $5 \%$ in- jection of $\mathrm{CO}_{2}$. Cells were passaged every $48 \mathrm{~h}$ at $70-80 \%$ confluence and harvested by centrifugation. The physiological condition was maintained at $37^{\circ} \mathrm{C}$. Thermal inactivation was carried out by incubating the A459 and HeLa cell dish for 30 min in a thermostat with the set temperatures of 42,46 , and $50{ }^{\circ} \mathrm{C}$. Harvested cells were sonicated and washed with $100 \%$ acetone. Finally, dry cells were dissolved in a lysis buffer.

Co-immunoprecipitation (Co-IP). A549 and HeLa cells were transfected with PCMV-FLAG and pCMV-HA plasmids harboring CKBB and Prx II genes. The hybrid pCMV-HA/Prx II and pCMVFLAG/CKBB plasmids were kindly presented by the Professor Chae's laboratory. Cell lysate with pCMVFLAG and pCMV-HA was precipitated with the Red Anti-Flag M2 Affinity Gel (Sigma, USA) according to manufacturer's manual. The immobilized proteins were collected by centrifugation, washed with TBS buffer ( $50 \mathrm{mM}$ Tris-HCl, $150 \mathrm{mM} \mathrm{NaCl}$ ), and solubilized by cooking the affinity gel beads with 2x SDS-PAGE sample buffer. The cooked samples were analyzed with $12 \%$ SDS-PAGE, followed by immunoblotting.

One-dimensional SDS-PAGE. For SDSPAGE protein samples were prepared with 2x sample buffer (0.5 M Tris-HCl, pH 6.8, 4\% SDS, 10\% $\beta$-mercaptoethanol, $20 \%$ glycerol, $0.1 \%$ bromphenol blue) and heated at $95{ }^{\circ} \mathrm{C}$ for $5 \mathrm{~min}$. Samples were run on $5 \%$ stacking gel and $12 \%$ acrylamide separating gel. Electrophoresis was carried out at a 70-150V range (Power Pack 1000, Bio-Rad) using 1x SDS-PAGE buffer (0.5M Tris-HCl, pH 6.8, 2\% SDS, $5 \% \beta$-mercaptoethanol, $10 \%$ glycerol, $0.1 \%$ bromphenol blue).

Immunoblotting. For immunoblot analysis, the gel from SDS-PAGE was carefully soaked in a transfer buffer (25 mM Tris, $192 \mathrm{mM}$ glycine, 20\% $\mathrm{MeOH})$. Nitrocellulose blotting membrane (3 M) of gel size was assembled into sandwich using the tank cassette and placed into the blotting tank. The transfer was conducted under $100 \mathrm{~V}$ during $50 \mathrm{~min}$. The blots were washed for $10 \mathrm{~min}$ in TBS-T ( $25 \mathrm{mM}$ Tris, $150 \mathrm{mM} \mathrm{NaCl}, 0.1 \%$ tween-20, pH 8.3) with $5 \%$ horse serum or skim milk. Blotted nitrocellulose membrane was precipitated with primary polyclonal either with anti-Prx II or anti-CKBB antibody overnight at $4{ }^{\circ} \mathrm{C}$ and then washed four times in a TBS-T for $5 \mathrm{~min} /$ wash. The rabbit polyclonal anti-Prx II and anti-CKBB antibodies were kindly presented by the Professor Chae's laboratory. The nitrocellulose 
membrane was incubated with the secondary horseradish peroxidase-conjugated goat anti-rabbit polyclonal antibody (Abcam 97051) for $1 \mathrm{~h}$ at room temperature and again washed four times in a TBS-T for $5 \mathrm{~min} /$ wash. At last, the blot was immersed in $10 \mathrm{ml}$ of AP buffer (100 mM NaCl, 100 mM Tris, 5 mM $\left.\mathrm{MgCl}_{2}, \mathrm{pH} 9.5\right)$ and visualized using NBT $(0.5 \mathrm{~g} / \mathrm{ml}$ in $70 \%$ dimethylforamide) and BCIP (0.25 g/ml in 100\% dimethylforamide) system.

\section{Results and Discussions}

2-Cys Prxs show high specificity toward target proteins with regard to the site-specific association. Apoptosis signal-regulating kinase 1 (ASK1) under resting conditions interacts with the $\mathrm{NH}_{2}$-terminal Trx-binding domain of Prx I with marked enhancement of the ASK1-Prx I binding affinity under $\mathrm{H}_{2} \mathrm{O}_{2}$ stimulation [21]. In addition, it has been demonstrated that a molecular complex of Cdk5/p35 and endogenous Prx II can be formed in vivo with consequent phosphorylation of Prx II at $\mathrm{Thr}^{89}$ residue and inhibition of its peroxidase activity [22]. Another example proves that Prx I can specifically bind the MIF-interacting protein in vivo, where the conserved
$\mathrm{Cys}^{173}$ plays a pivotal role in the formation of intramolecular disulfide linkage between MIF and Prx I [23].

In order to assess the interaction of Prx II with CKBB, we performed co-immunoprecipitation assay using lysates from A549 cells transfected with Flag-CKBB and HA-Prx II or empty vector alone as negative control. In A549 cells, the level of Prx II is established to be at very low concentrations [24]. As shown in (Fig. 1, A, WCL; bottom panel) western blot analysis on the whole cell lysates the levels of Flag-CKBB or HA-Prx II were detected in the transfected A549 cells, indicating successful expression of proteins. After immunoprecipitation with antiFlag M2 affinity gel, we confirmed that Flag-CKBB interacts with exogenous HA-Prx II (Fig. 1, A, IP; upper panel).

Further, we evaluated whether the binding of CKBB to Prx II can be affected by the heat-induced stress conditions. After cell transfection, they were incubated for $30 \mathrm{~min}$ at 42, 46 and $50{ }^{\circ} \mathrm{C}$ followed by co-immunoprecipitation using anti-Flag M2 affinity gel. SDS-PAGE analysis of A549 cell lysates with overexpressed plasmid constructs demonstrated

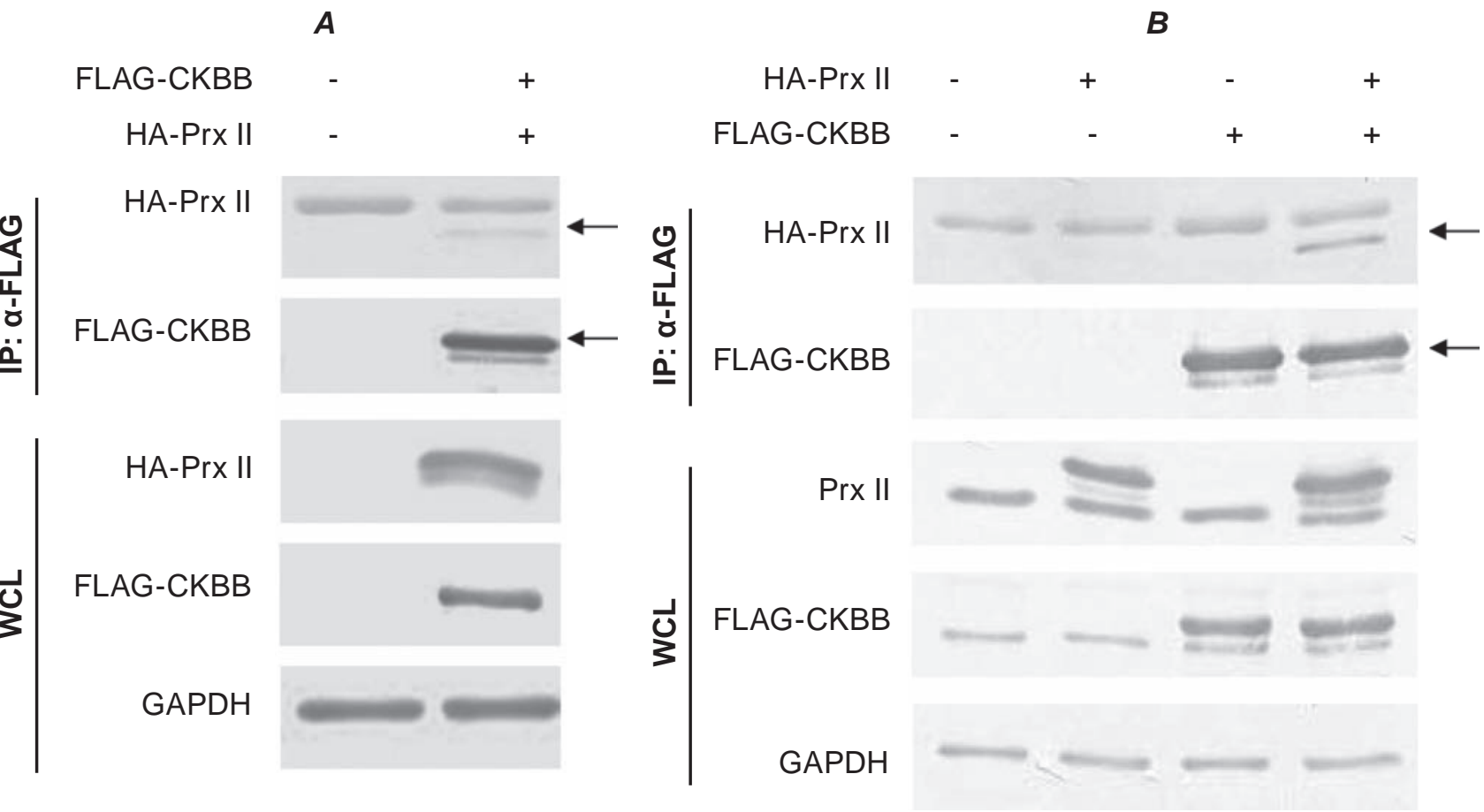

Fig. 1. Interaction of Prx II with CKBB in A549 (A) and HeLa (B) cells under physiological conditions. Cultured cells were transfected with the plasmids harboring Flag-CKBB and HA-Prx II. Cell lysates were subjected to the co-immunoprecipitation assay with anti-Flag resin. Immune complexes were separated on the SDS-PAGE gel, where Prx II and CKBB proteins were visualized with polyclonal anti-Prx II and anti-CKBB antibodies respectively. The GAPDH level was used as a loading control 
A

$\begin{array}{rccccccc}\text { HA-Prx II } & - & + & - & + & + & + & + \\ \text { FLAG-CKBB } & - & - & + & + & + & + & + \\ \text { Heat }\left({ }^{\circ} \mathrm{C}\right) & - & - & - & - & 42 & 46 & 50\end{array}$

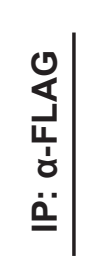

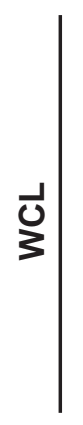

B

HA-Prx II

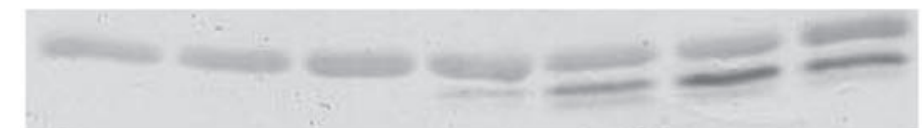

FLAG-CKBB

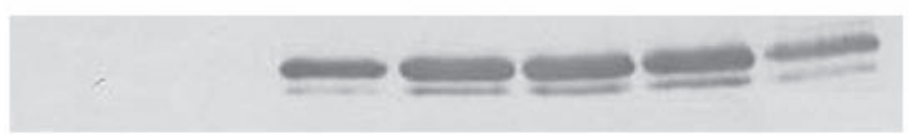

Prx II

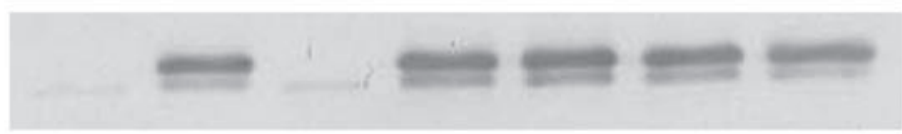

FLAG-CKBB

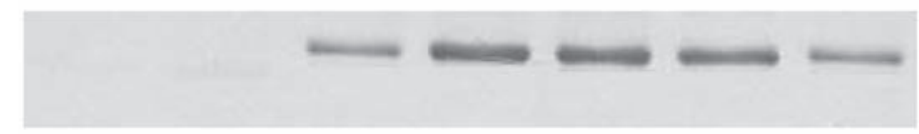

GAPDH

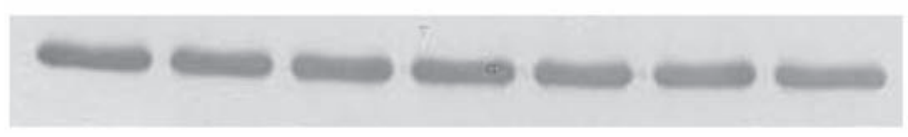

HA-Prx II

FLAG-CKBB

Heat $\left({ }^{\circ} \mathrm{C}\right)$

$+\quad+$

$-$

$+$

$+\quad+\quad+$

$+\quad+$

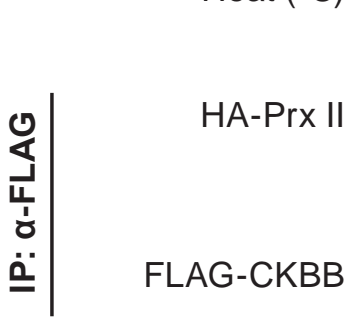

ذي

Prx II

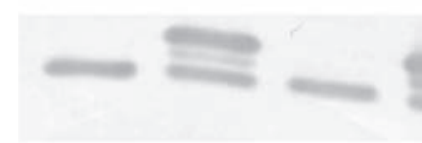

$42 \quad 46$

50

Fig. 2. Interaction of Prx II with CKBB in A549 (A) and HeLa (B) cells under heat stress. A549 and HeLa cells were transiently transfected with the plasmids encoding Flag-CKBB and HA-Prx II constructs. Prior to harvest, cells were exposed to the thermal stress with indicated temperatures for $30 \mathrm{~min}$. Cell lysates were co-immunoprecipitated with the anti-FLAG resin according to the manufacture's protocol. The samples were separated using SDS-PAGE, followed by immunoblotting with anti-Prx II and anti-CKBB antibodies 
complex formation of HA-Prx II with Flag-CKBB. Prx II interacted with Flag-CKBB under normal growth conditions $\left(37^{\circ} \mathrm{C}\right)$ and their interaction was enhanced by the temperature increase from $37^{\circ} \mathrm{C}$ to $50{ }^{\circ} \mathrm{C}$ (Fig. 2, A, IP; upper panel). The peak of interaction strength was registered at $46^{\circ} \mathrm{C}$ with reduction of interaction capacity at $50^{\circ} \mathrm{C}$.

To compare the difference of Prx II interacting with CKBB, we conducted co-immunoprecipitation experiments using HeLa cells containing endogenous Prx II and transfected exogenous HA-Prx II. HeLa cells were previously reported to contain about $3.3 \mu \mathrm{g}$ Prx II in $1 \mathrm{mg}$ of soluble protein [25]. HeLa cells were transfected with plasmids encoding FlagCKBB, HA-Prx II, Flag-CKBB and Prx II or empty vector alone and co-immunoprecipitated using antiFlag M2 affinity gel. We observed that exogenous HA-Prx II interacts with Flag-CKBB under physiological conditions (Fig. 1, B, IP; upper panel) and their interaction was enhanced by the temperature treatment in the similar manner with A549 cells (Fig. 2, B, IP; upper panel). Therefore, with elevated temperature treatment in both A549 and HeLa cells lines we see increase in binding strength, suggesting possibly more rapid Prx II-CKBB complexes formation.

Oxidative modifications of proteins and lipids have been blamed for progression of many neurodegenerative disorders [26]. Using a proteomic approach, CKBB was identified as one of oxidized proteins in Alzheimer's disease (AD) [27]. Consequently, CK activity in the AD brain homogenates was decreased by $86 \%$ [28]. Thus, identification of CKBB as the interaction partner of Prx II may provide an important insight not only into a possible physiological role of Prxs protein family, but also to the pathological role of Prx II in the neurodegeneration development associated with $\mathrm{AD}$ and $\mathrm{CKBB}$ activity decrease.

\section{ВЗАСМОДІЯ ПРОТЕЇНІВ Prx II ТА СКВВ ЗА УМОВ ТЕПЛОВОГО СТРЕСУ В КЛІТИНAХ A549 TA HeLa}

\author{
А. Д. Рахметов ${ }^{1}$ Лі Сан-Піль \\ Л. I. Остапченко ${ }^{1}$ Чає Хо-Зун
}

${ }^{1}$ ННЦ «Інститут біології», Київський національний університет імені Тараса Шевченка, Україна;

${ }^{2}$ Чоннамський національний університет, Кванджу, Південна Корея; e-mail: anar.rakhmetov@gmail.com

Пероксиредоксини (Prxs) - це універсальні ензими, які демонструють різноманіття клітинних функцій, таких як: пероксидазна, шаперонна, модуляторів сигнальних молекул та протеїнів-партнерів. Встановлено, що Prxs у клітині взаємодіють із багатьма функціональними протеїнами, наприклад: ASK1, Cdk5-p35, JNK, MIF, PDGF, TKR4 та ін. Звідси головною метою нашої роботи було дослідити можливу взаємодію між мультифункціональним протеїном Prx II сімейства Prxs i ATP/ADP буферним ензимом - креатинфосфокіназою головного мозку (CKBB). Завдяки реакції коімунопреципітації (Co-IP) показано взаємодію надекспресованих HA-Prx II i Flag-CKBB протеїнів у лізатах клітин A549 та HeLa. Така протеїн-протеїнова асоціація була додатково індукована температурним стресом із подальшою преципітацією сигналу залежно від підвищення температури. Температурноіндукована олігомеризація $\operatorname{Prx}$ II, ймовірно, сприяє формуванню $\operatorname{Prx}$ II-конгломератів, які в свою чергу можуть зв'язуватись із СКВВ та ініціювати підвищення інтенсивності сигналу на блоті. Таким чином, асоціація між Prx II та CKBB може бути пов'язана 3 відновленням та захистом ензиматичної активності CKBB, яка була втрачена під час інактивації за дії підвищеної температури.

К л ю чов і слов а: пероксиредоксин II, температурний стрес, креатинфосфокіназа, вестерн-блотинг. 


\section{ВЗАИМОДЕЙСТВИЕ ПРОТЕИНОВ PrX II И СКВВ ПРИ ТЕПЛОВОМ СТРЕССЕ В КЛЕТКАХ A549 И HeLa}

\author{
А. Д. Рахметов ${ }^{1}$ Ли Сан-Пиль ${ }^{2}$, \\ Л. И. Остапченко ${ }^{1}$ Чае Хо-Зун \\ 1УНЦ «Институт биологии», Киевский \\ национальный университет имени \\ Тараса Шевченко, Украина; \\ ${ }^{2}$ Чоннамский национальный университет, \\ Кванджу, Южная Корея; \\ e-mail: anar.rakhmetov@gmail.com
}

Пероксиредоксины (Prxs) - это универсальные энзимы, которые демонстрируют многообразие клеточных функций, таких как: пероксидазная, шаперонная, модуляторов сигнальных молекул и протеинов-партнеров. Установлено, что Prxs в клетке взаимодействуют со многими функциональными протеинами, например ASK1, Cdk5-p35, JNK, MIF, PDGF, TKR4 и др. Отсюда главной целью нашей работы было исследовать возможное взаимодействие между мультифункциональным протеином Prx II ceмейства Prxs и ATP/ADP буферным энзимом креатинфосфокиназой головного мозга (CKBB). Благодаря реакции коиммунопреципитации (Co-IP) показано взаимодействие синтезированных НA-Prx II и Flag-CKBВ протеинов в лизатах клеток A549 и HeLa. Такая протеин-протеиновая ассоциация была дополнительно индуцирована температурным стрессом с последующей преципитацией сигнала на блоте в зависимости от повышения температуры. Температурноиндуцированная олигомеризация Prx II, вероятно, способствует формированию Prx II конгломератов, которые в свою очередь могут связываться с СКВВ и инициировать повышение интенсивности сигнала. Таким образом, такая ассоциация между Prx II и CKBB может быть связана с восстановлением и защитой энзиматической активности СКВВ, которая теряется во время температурной инактивации.

К л ю че вы е с ло в а: пероксиредоксин II, температурный стресс, креатинфосфокиназа, вестерн-блоттинг.

\section{References}

1. Jang H. H., Lee K. O., Chi Y. H., Jung B. G., Park S. K., Park J. H., Lee J. R., Lee S. S., Moon J. C., Yun J. W., Choi Y.O., Kim W. Y., Kang J. S., Cheong G. W., Yun D. J., Rhee S. G., Cho M. J., Lee S. Y. Two enzymes in one; two yeast peroxiredoxins display oxidative stressdependent switching from a peroxidase to a molecular chaperone function. Cell. 2004; 117(5): 625-635.

2. König J., Galliardt H., Jütte P., Schäper S., Dittmann L., Dietz K. J. The conformational bases for the two functionalities of 2-cysteine peroxiredoxins as peroxidase and chaperone. J. Exp. Bot. 2013; 64(11): 3483-3497.

3. Chae H. Z., Robison K., Poole L. B., Church G., Storz G., Rhee S. G. Cloning and sequencing of thiol-specific antioxidant from mammalian brain: alkyl hydroperoxide reductase and thiolspecific antioxidant define a large family of antioxidant enzymes. Proc. Natl. Acad. Sci. USA. 1994; 91(15): 7017-7021.

4. Rhee S. G., Woo H. A. Multiple functions of peroxiredoxins: peroxidases, sensors and regulators of the intracellular messenger $\mathrm{H}_{2} \mathrm{O}_{2}$, and protein chaperones. Antioxid. Redox Signal. 2011; 15(3): 781-794.

5. Chae H. Z., Oubrahim H., Park J. W., Rhee S. G., Chock P. B. Protein glutathionylation in the regulation of peroxiredoxins: a family of thiol-specific peroxidases that function as antioxidants, molecular chaperones, and signal modulators. Antioxid. Redox Signal. 2012; 16(6): 506-523.

6. Lowther W. T., Haynes A. C. Reduction of cysteine sulfinic acid in eukaryotic, typical 2-Cys peroxiredoxins by sulfiredoxin. Antioxid. Redox Signal. 2011; 15(1): 99-109.

7. Biteau B., Labarre J., Toledano M. B. ATPdependent reduction of cysteine-sulphinic acid by S. cerevisiae sulphiredoxin. Nature. 2003; 425(6961): 980-984.

8. Woo H. A., Jeong W., Chang T. S., Park K. J., Park S. J., Yang J. S., Rhee S. G. Reduction of cysteine sulfinic acid by sulfiredoxin is specific to 2-cys peroxiredoxins. J. Biol. Chem. 2005; 280(5): 3125-3128. 
9. Kinnula V. L., Lehtonen S., Sormunen R., Kaarteenaho-Wiik R., Kang S. W., Rhee S. G., Soini Y. Overexpression of peroxiredoxins I, II, III, V, and VI in malignant mesothelioma. J. Pathol. 2002; 196(3): 316-323.

10. Noh D. Y., Ahn S. J., Lee R. A., Kim S. W., Park I. A., Chae H. Z. Overexpression of peroxiredoxin in human breast cancer. Anticancer Res. 2001; 21(3B): 2085-2090.

11. Karihtala P., Mäntyniemi A., Kang S. W., Kinnula V. L., Soini Y. Peroxiredoxins in breast carcinoma. Clin. Cancer Res. 2003; 9(9): 34183424.

12. Park S. H., Chung Y. M., Lee Y. S., Kim H. J., Kim J. S., Chae H. Z., Yoo Y. D. Antisense of human peroxiredoxin II enhances radiationinduced cell death. Clin. Cancer Res. 2000; 6(12): 4915-4920.

13. Chung Y. M., Yoo Y. D., Park J. K., Kim Y. T., Kim H. J. Increased expression of peroxiredoxin II confers resistance to cisplatin. Anticancer Res. 2001; 21(2A): 1129-1133.

14. Han Y. H., Kim S. U., Kwon T. H., Lee D. S., Ha H. L., Park D. S., Woo E.J., Lee S. H., Kim J. M., Chae H. B., Lee S. Y., Kim B. Y., Yoon do Y., Rhee S. G., Fibach E., Yu D. Y. Peroxiredoxin II is essential for preventing hemolytic anemia from oxidative stress through maintaining hemoglobin stability. Biochem. Biophys. Res. Commun. 2012; 426(3): 427-432.

15. Lee W., Choi K. S., Riddell J., Ip C., Ghosh D., Park J. H., Park Y. M. Human peroxiredoxin 1 and 2 are not duplicate proteins: the unique presence of CYS83 in Prx1 underscores the structural and functional differences between Prx1 and Prx2. J. Biol. Chem. 2007; 282(30): 22011-22022.

16. Wallimann T., Wyss M., Brdiczka D., Nicolay K., Eppenberger H. M. Intracellular compartmentation, structure and function of creatine kinase isoenzymes in tissues with high and fluctuating energy demands: the 'phosphocreatine circuit' for cellular energy homeostasis. Biochem. J. 1992; 281(Pt 1): 21-40.

17. Aksenov M., Aksenova M., Butterfield D. A., Markesbery W. R. Oxidative modification of creatine kinase BB in Alzheimer's disease brain. J. Neurochem. 2000; 74(6): 2520-2527.
18. Aksenov M. Y., Aksenova M. V., Butterfield D. A., Geddes J. W., Markesbery W. R. Protein oxidation in the brain in Alzheimer's disease. Neuroscience. 2001; 103(2): 373-383.

19. Kim J., Amante D. J., Moody J. P., Edgerly C. K., Bordiuk O. L., Smith K., Matson S. A., Matson W. R., Scherzer C. R., Rosas H. D., Hersch S. M., Ferrante R. J. Reduced creatine kinase as a central and peripheral biomarker in Huntington's disease. Biochim. Biophys. Acta. 2010; 1802(7-8): 673-681.

20. Pace P. E., Peskin A. V., Han M. H., Hampton M. B., Winterbourn C. C. Hyperoxidized peroxiredoxin 2 interacts with the protein disulfide- isomerase ERp46. Biochem. J. 2013; 453(3): 475-485.

21. Kim S. Y., Kim T. J., Lee K. Y. A novel function of peroxiredoxin 1 (Prx-1) in apoptosis signalregulating kinase 1 (ASK1)-mediated signaling pathway. FEBS Lett. 2008; 582(13): 1913-1918.

22. Qu D., Rashidian J., Mount M. P., Aleyasin H., Parsanejad M., Lira A., Haque E., Zhang Y., Callaghan S., Daigle M., Rousseaux M. W., Slack R. S., Albert P. R., Vincent I., Woulfe J. M., Park D. S. Role of Cdk5-mediated phosphorylation of Prx2 in MPTP toxicity and Parkinson's disease. Neuron. 2007; 55(1): 37-52.

23. Jung H., Kim T., Chae H. Z., Kim K. T., Ha H. Regulation of macrophage migration inhibitory factor and thiol-specific antioxidant protein PAG by direct interaction. J. Biol. Chem. 2001; 276(18): 15504-15510.

24. Kinnula V. L., Lehtonen S., KaarteenahoWiik R., Lakari E., Pääkkö P., Kang S. W., Rhee S. G., Soini Y. Cell specific expression of peroxiredoxins in human lung and pulmonary sarcoidosis. Thorax. 2002; 57(2): 157-164.

25. Chae H. Z., Kim H. J., Kang S. W., Rhee S. G. Characterization of three isoforms of mammalian peroxiredoxin that reduce peroxides in the presence of thioredoxin. Diabetes Res. Clin. Pract. 1999; 45(2-3): 101-112.

26. Butterfield D. A., Lauderback C. M. Lipid peroxidation and protein oxidation in Alzheimer's disease brain: potential causes and consequences involving amyloid beta-peptideassociated free radical oxidative stress. Free Radic Biol. Med. 2002; 32(11): 1050-1060. 
27. Castegna A., Aksenov M., Aksenova M., Thongboonkerd V., Klein J. B., Pierce W. M., Booze R., Markesbery W. R., Butterfield D. A. Proteomic identification of oxidatively modified proteins in Alzheimer's disease brain. Part I: creatine kinase $\mathrm{BB}$, glutamine synthase, and ubiquitin carboxy-terminal hydrolase L-1. Free Radic Biol. Med. 2002; 33(4): 562-571.
28. David S., Shoemaker M., Haley B. E. Abnormal properties of creatine kinase in Alzheimer's disease brain: correlation of reduced enzyme activity and active site photolabeling with aberrant cytosol-membrane partitioning. Mol. Brain Res. 1998; 54(2): 276-287.

Received 14.09.2015 